\section{Enhancing supply resilience in the COVID-19 pandemic: a case study on beauty and personal care retailers}

Enhancing supply

resilience in the pandemic

Md. Tarek Chowdhury

Abdul Monem Limited, Barishal, Bangladesh

Aditi Sarkar

Independent Researcher, Melbourne, Australia

Pronab Kumer Saha

Sylhet International University, Sylhet, Bangladesh, and

Rakib Hasan Anik

Bangladesh University of Professionals, Dhaka, Bangladesh
Received 25 July 2020 Revised 21 September 2020 19 October 2020

Accepted 19 October 2020

\begin{abstract}
Purpose - The COVID-19 pandemic interrupts the supply chain of products around the world. The supply chains of beauty and personal care products in Bangladesh are also heavily interrupted during this pandemic. While these products are perceived as essential by mass people, retailers are struggling to get the supply of the products and maintain a smooth delivery to the people. Considering such facts, the purposes of the study are to identify how the supply of retailers of these products is interrupted and how they can overcome the interruptions to ensure supply resilience.

Design/methodology/approach - A case study method has been used in this study. The data has been collected through interviews from 16 retailers of beauty and personal care products.

Findings - The results show that the supply of retailers of beauty and personal care products is interrupted in several ways. These include product shortage, limited delivery service, interruption of supplier payment, limited credit facility and irregularity in product delivery. To minimize the impacts of the interruptions and enhance supply resilience, retailers can undertake several strategies including intensive interactions and developing cooperation with the distributors and manufacturers, ordering bulk quantity, formulating an adjusted credit ratio and focusing on product availability over brand preference.

Research limitations/implications - The context of this study is limited to the beauty and personal care products of Bangladesh. Further study can be conducted in other countries and also supply chains of other products to enhance the generalizability of the findings of this study.

Practical implications - Supply interruptions are identified, and strategies are suggested to ensure the supply resilience of retailers of beauty and personal care products. If proposed strategies are implemented by retailers of these products, supply interruptions can be minimized.

Originality/value - The study contributes to the knowledge of the retail supply chain during a pandemic. It also contributes to the supply management and resilience of retailers. As the context is a developing country, the study also contributes to the literature on developing countries.
\end{abstract}

Keywords Supply resilience, Beauty and personal care retailers, COVID-19, Supply chain interruptions Paper type Research paper

(C) Md. Tarek Chowdhury, Aditi Sarkar, Pronab Kumer Saha and Rakib Hasan Anik. Published in Modern Supply Chain Research and Applications. Published by Emerald Publishing Limited. This article is published under the Creative Commons Attribution (CC BY 4.0) license. Anyone may reproduce, distribute, translate and create derivative works of this article (for both commercial and non-commercial purposes), subject to full attribution to the original publication and authors. The full terms of this license

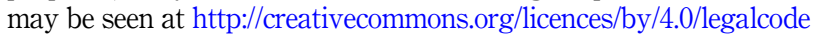


MSCRA

2,3

144

\section{Introduction}

The COVID-19 outbreak has a substantial negative impact on both public health issues such as illness and mental well-being and other economic activities such as employment and flow of commercial supply chain. The pandemic affected operations of 9,038 companies out of the listed Fortune 1,000 companies (Fortune, 2020). Economic growth has also slowed down due to the pandemic (Chalabi, 2020; ILO, 2020). According to the World Bank, the global economy may contract $5.2 \%$ (World Bank, 2020). Policymakers of all over the world are trying to find solutions to minimize the impact on the economy and commercial supply chains. Academicians are also researching how to recover the loss that businesses and their supply chains are facing during the situation. This outbreak has impacted almost all the supply chains of the globe as many players are involved from various locations in a supply chain (Paul and Chowdhury, 2020a). Indeed, supply chains face many disruptions (Paul et al., 2014a, 2015a; Pettit et al., 2010). Managing these disruptions and ensuring resilience is important (Kahiluoto and Makinen, 2019) to gain competitive advantages (Kwak et al., 2018). The current pandemic is extraordinary and breaks all the previous records in terms of the severity of a supply chain disruption on the operation (Ivanov, 2020a, b; Lin et al., 2020). All the players in a supply chain are affected by this outbreak (Chowdhury et al., 2020).

Retail supply chains are also severely affected by the current pandemic. However, so far, no research has focused on the retailers considering this COVID-19 outbreak. Given that retailers are the key partners in supply chain systems because of their direct involvement to meet the customer's demand (Sparks, 2010), many previous studies, such as (Salehi Sadghiani et al., 2015), suggested considering disruptions in the retail chain. Due to the limited transportation, restrictions of the government and limited operations of the distributors and wholesalers, retailers are facing problems for procuring goods from their suppliers during the COVID-19 situation. Proper management of this supply to ensure resilience is important at this stage as general customers may panic if the products are not available. This is more important for beauty and personal care products as customers perceive these products as essential. For example, a study conducted by Masory (2019) found that $72 \%$ of respondents consider the beauty and personal care products as important to them. Here beauty and personal care products mean products that are consumed by an individual for personal health, hygiene or cosmetic reasons. Therefore, practitioners of retail stores need to think how they can make their supply resilient during a disruption. In order to assist retailers in this regard during the current COVID-19, in this study we want to seek the answer to the following two questions:

(1) What are the effects of the COVID-19 on the supply of beauty and personal care retailers?

(2) What strategies might be undertaken to improve supply resilience?

Exploring the answer to such questions is vital because the demand for essential products, including beauty and personal care products, has accelerated during the COVID-19 situation (Paul and Chowdhury, 2020a). Ivanov (2020b) also mentioned that demand for some essential products such as a mask, sanitizer had increased tremendously. Top executives of a wellreputed US retailer, Target, told that demand for essential products had increased by $50 \%$ in March (Hoek, 2020). In the COVID-19 situation, people use more beauty and personal care products than normal situation due to health issues. In this study, we have considered Bangladesh as the context of our investigation. Bangladesh, like other economies of the world, has been severely affected by this outbreak (Bhuiyan, 2020). For instance, ADB has an estimation that the economy of Bangladesh would contract by $1.1 \%$ (UNB, 2020). The study considers only small retailers. Abir (2019) noted that in Bangladesh, only $1 \%$ of retail stores are organized or big stores, while $99 \%$ are small retail stores. These unorganized stores are 
denoted as mom and pop shop (Mudir Dokan) by him. Generally, in the south Asian countries including Bangladesh, people collect beauty and personal care products from their nearby small retailers. If the retailers do not get regular supply, it may create an unexpected situation for retailers as well as general people. By considering small retailers of Bangladesh as the subject, the findings of this study can serve as the guide for these huge number of retailers to manage their supply side to ensure supply resilience. The findings are expected to assist the retailers in obtaining the regular product from suppliers, thereby maintaining flawless product delivery to mass people. As such, it can assist general people to get their regular essential beauty and personal care products. The findings of this study also contribute to the literature of retail supply chain, which is currently scarce.

The remainder of the paper is organized as follows: Section 2 of our paper contains literature on supply resilience, pandemic outbreak and supply resilience and supply resilience in the retail supply chain. The research methodology is explained in Section 3. Section 4 contains the findings of the study. The implication is discussed in Section 5. Conclusion and future research directions are described in Section 6.

\section{Literature review}

In this section, we conducted a literature review on supply resilience, pandemic outbreak and supply resilience and supply resilience of the retail supply chain. Based on the findings of the current literature, we identified the knowledge gaps to highlight the contributions of this study.

\subsection{Supply resilience}

Disruptions in supply chains are inevitable (Paul et al., 2014b, 2015b, 2017, 2018). When a disturbed or disrupted supply chain is capable of returning to its original state, it is called resilient (Pettit et al., 2010). A resilient supply chain is capable of performing operation during an unprecedented event (Blackhurst et al., 2011). Besides, it is also believed that resilience is also related to a system that assists supply chains to recover and come back to its previous state quickly (Mitroff and Alpasan, 2003). Christopher and Peck (2004) defined resilience as: "the ability of a system to return to its original state or move to a new, more desirable state after being disturbed." In general, if an enterprise can endure, adjust and grow in a turbulent environment, then we can consider that it is resilient (Fiksel, 2006). According to the same research (Fiksel, 2006), other characteristics of a resilient supply chain include efficiency, adaptability and cohesion. In order to help assessing supply chain disruptions for building a resilient supply chain, Ali and Nakade (2017) proposed a model for supply chain disruptions named as conditional value at risk $(\mathrm{CVaR})$ model.

The two main approaches of maintaining resilience are proactive and reactive (Wielend and Wallenburg, 2013). Reduction of probability of risk events is proactive, but in reality, we have to face risks and disruptions (Fartaj et al., 2019; Paul, 2015; Saha et al., 2020). Moreover, only operational risks, which originate from internal problems, of supply chains can be controlled (Chowdhury et al., 2016, 2019). However, disruptions originate from external sources (Ponomarov and Holcomb, 2009) and are uncontrollable (Paul et al., 2016). These supply chain disruptions have negative impacts on performance of firms and overall chain resilience. Disruptions in the supply side of the supply chain have been increasing (Bahroun and Harbi, 2016; Gunasekaran et al., 2015; Paul et al., 2019b; Paul and Rahman, 2018a, b). Disruptions in supply happened by many hazards such as earthquakes, hurricanes and SARS (Wagner and Bode, 2006). Both natural and human-made (terrorist attack) calamities can be the reasons of supply disruption (Islam et al., 2020; Paul et al., 2019b; Tang, 2006; Wagner and Neshat, 2010). 
MSCRA

2,3

146

\subsection{Pandemic outbreak and supply resilience}

A recent study (Hudecheck et al., 2020) mentioned that more than 1,400 epidemics had occurred, which hampered business activities. Moreover, Blos and Wee (2020) added two risks, rainfall and viral epidemics, in the supply chain vulnerability map (SCVMII). This clearly outlines the criticality of considering the impacts of epidemic outbreaks in supply chain resilience strategies. The recent COVID-19 outbreak further stresses the researchers to investigate supply chain resilience considering epidemic and pandemic outbreaks (Paul and Chowdhury, 2020a). While supply of all firms including small firms is affected by the current pandemic, currently, there are no clear guidelines for the manager of small firms. Holding cash for 1-3 months, finding options for relaxation of instalment of the loan, holding buffer stock, relation with key suppliers were suggested for SMEs (Hudecheck et al., 2020). Ivanov (2020a) treated pandemic as an outstanding risk of supply chains. This pandemic causes disruptions in the long run, ripple effect and uncertainty to supply chains. The findings of Ivanov (2020a) help forecasting and making a plan for supply chains during a pandemic. Another study (Koonin, 2020) also suggested that an organization should plan for its customers, community, crew and continuity of business during a pandemic.

Dual disruptions are created during the current pandemic; one is demand variation, another is supply variation (Paul and Chowdhury, 2020a; Ivanov, 2020b and Koonin, 2020). It is also warned that the impact of the COVID-19 pandemic is long-lasting. Risks diminish value creation in a supply chain (Bogataj and Bogataj, 2007). Given that all the supply chains have been disrupted during COVID-19 (Paul and Chowdhury, 2020b), formulation of resilience strategies is essential to help the organization to overcome the supply chain disruptions (Ambulkar et al., 2014). Due to new experiences, decision-makers would face challenges in recovery planning (Paul and Chowdhury, 2020a). Moreover, most of the literature on epidemics and pandemics emphasized on humanitarian logistics and ignored commercial organizations (Paul and Chowdhury, 2020a; Ivanov, 2020a). However, the impacts of such epidemics and pandemics are severe on commercial supply chains (Laing, 2020). It also heavily shakes the supply chain of the retail stores. Hence, the study aims at providing strategies to make the retailers' supply resilient.

\subsection{Supply resilience in retail supply chain}

A retailer generally has direct linkages with three supply chain members such as wholesalers, distribution centers and customers and indirect linkages with manufacturers and their suppliers (Ge et al., 2019). Retailers are a crucial part of the supply chain (Fleisch and Tellkamp, 2005) because of their proximity to customers (Wang and Liu, 2007). It is clear that COVID-19 affects all supply chain partners including manufacturers, retailers, wholesalers (Sharma et al., 2020). The panic buying of essential products by the end customers leads to disruption to supply chains (Yuen et al., 2020) and creates demand-side shocks (Hobbs, 2020). Retailers as well as other members of supply chains are struggling hard to meet consumers' needs (De Sousa Jabbour et al., 2020). While retailers have faced panic buying from consumers, they have faced disruptions in product supply from the companies during the current pandemic (Kumar et al., 2020). Kumar et al. (2020) pointed out 12 challenges confronted by retailers, such as lack of balance in supply and demand, lack of access, lack of viability, communication issues and provided guidelines to overcome the challenges. Generally, retailers source products from the wholesalers and distributors. High dependency on these suppliers is the main reason for the disruption in retailers (Gupta et al., 2020). Accordingly, Yu and Aviso (2020) emphasized the importance of finding better approaches to mitigate the effects of a pandemic.

Considering the importance of a resilient retail supply chain, this study aims to find out whether the retailer faces any sourcing problem during the pandemic and to suggest some 
strategies to overcome the problems. We have considered the retail supply chain of beauty and personal care products in Bangladesh. Disruptions at the retail point are denoted as downstream disruptions (Sarkar and Kumar, 2015). Disruptions in the supply chain during COVID-19, manufacturing firms are highlighted in previous studies (Paul and Chowdhury, 2020a, b). However, no study considered the supply disruptions of retailers. Moreover, to date, no study has considered the context of beauty and personal care supply chains. We argue that managing disruption in this sector is important as some of these products are essential. The effects of unpredicted disruptions on supply side of retailers can be mitigated by implementing appropriate supply resilience strategies (Golan et al., 2020). Therefore, the context of the study, exploring the effect of COVID-19 and providing supply resilience strategies for the retailers, seems appropriate and timely.

\section{Methodology}

The study adopts a case study methodology in obtaining and analyzing the data. The main reason for adopting a case-study-based methodology is that an in-depth and exploratory investigation is needed in this study (Yin, 2009). A case study research generally provides indepth understandings of a topic that is less explored in the literature (Eisenhardt, 1989). Given that there are inadequate studies in the literature to answer the questions of how retailers' supply management is interrupted during a pandemic and how they can make their supply resilient, in-depth exploration is required to achieve the objectives of this study. Therefore, the case study research seems most appropriate for this study. The details of data collection and analysis are explained in the following subsection.

\subsection{Data collection method}

Semistructured and in-depth interviews, which are a qualitative approach, are used in this study for data collection. Managers of the retail store are the main respondents of interview questions. However, all the respondents are also the owners of the retail stores. This is very usual in a developing country like Bangladesh where owners manage their stores. We have collected the data from 16 retail firms, one respondent from each firm, where each retail firm is considered as a case. In a case-study-based research, 16 cases are considered sufficient to understand the phenomena under investigation (Yin, 2009). The 16 retail cases are selected from four divisions, namely Khulna, Barishal, Dhaka and Chittagong, to remove the location biasness. The cases are selected based on their retail locations to cover four out of eight divisions of Bangladesh and retail business experience (at least eight years to ensure the respondents are knowledgeable to answer the questions). The participating retail stores of this study have only 1-3 employees that denotes that they all are small firms. The year of experience of managing retail stores varies from 8 to 22 years for our respondents. Thus, they are knowledgeable enough to answer the questions of this study. All the respondents are involved in handling product supply. The duration of each interview is from 25 to $30 \mathrm{~min}$ to get a desirable understanding. Physical visit to the retail store has been done to collect the data and some interactions took place outside the retail store. The lead author of this study conducted the interviews. Before the interviews, all the respondents were well informed about the research objectives of the project to avoid any sort of misunderstanding while conducting the interviews. The interview was short but enough and comprehensive to satisfy our objectives. The detailed profile of the cases and respondents is given in Table 1.

\subsection{Research context}

The beauty and personal care market of Bangladesh is dominated by multinational companies such as Unilever Bangladesh Limited (Ltd), Reckitt Benckiser Bangladesh Ltd
Enhancing supply resilience in the pandemic 
MSCRA

2,3

148

and Marico Bangladesh Ltd. However, local companies provide limited similar kinds of products, and some importers import some other global brands of beauty and personal care and sell it in the local market (Huda and Sultan, 2013). Beauty and personal care products also come in different segments such as oral care, baby and child-specific products, fragrances, skincare or sun care specifically targeted for both male and female. Just only facewash product market is estimated to be $30.76 \mathrm{~m} \$$ by 2024 in Bangladesh and has seen a growth of $4.5 \%$ in every year (Mordor Intelligence LLP 2019). According to Bangladesh Cosmetics and Toiletries Manufacturer Association (BCTMA) (2019), almost half a million people are associated with this industry and annual turnover reached $150 \mathrm{bn}$ in that year. According to the Global Islamic Economy Report (2017), Bangladesh spends more money on beauty and personal care products. Beauty and personal care products have emerged as an essential product for Bangladeshi people, thus whenever the supply chain is disrupted due to any reason, it eventually affects all the stakeholders including mass people. Maintaining a smooth resilient supply chain is why necessary most. The market related to beauty and personal care products is quite sensitive because of its nature of products. Being a developing and densely populated country, Bangladesh is a large potential market for personal and beauty care products. Hence, the context of Bangladeshi personal and beauty care products poses an ideal platform to conduct this research.

\subsection{Data analysis}

The study systematically analyzed the data by categorizing and comparing the interviews (Signori et al., 2015). We have used within the case and cross-case analysis to investigate the phenomenon from a different perspective (Eisenhardt, 1989). To present the findings, we have used verbatim quotes, which reflect transparency and reliability (Yin, 2009). The quotes are used here to justify the effects and resilience strategies obtained via interviews.

\section{Findings and discussion}

This section presents the findings of the study. The findings are presented in two subsections: how the supply of retailers of beauty and personal care products is interrupted during COVID-19 and potential strategies to improve the supply resilience.

Table 1. Profile of the case respondents

\begin{tabular}{lllcc}
\hline Case & Respondents & Position of interviewee & Experience (in years) of the interviewee & Employee size \\
\hline Case A & R1 & Owner and Manager & 18 & 2 \\
Case B & R2 & Owner and Manager & 8 & 2 \\
Case C & R3 & Owner and Manager & 14 & 3 \\
Case D & R4 & Owner and Manager & 16 & 2 \\
Case E & R5 & Owner and Manager & 12 & 2 \\
Case F & R6 & Owner and Manager & 18 & 1 \\
Case G & R7 & Owner and Manager & 18 & 2 \\
Case H & R8 & Owner and Manager & 17 & 2 \\
Case I & R9 & Owner and Manager & 16 & 3 \\
Case J & R10 & Owner and Manager & 20 & 2 \\
Case K & R11 & Owner and Manager & 21 & 2 \\
Case L & R12 & Owner and Manager & 22 & 1 \\
Case M & R13 & Owner and Manager & 8 & 2 \\
Case N & R14 & Owner and Manager & 15 & 2 \\
Case O & R15 & Owner and Manager & 10 & 2 \\
Case P & R16 & Owner and Manager & 12 & 2 \\
\hline
\end{tabular}




\subsection{Supply interruption of beauty and personal care products of retailers}

This study investigates how the supply of the retailers of beauty and personal care products is interrupted during the COVID-19. As the retailer is the last person in the supply chain who deals with the ultimate customers, their supply disruption causes a huge impact on society.

Product shortage is found to be one of the main interruptions that have an impact during the COVID-19 on the supply of beauty and personal care products. The radical upstream demand for soap and liquid handwash cannot be fulfilled by the current capacity of the company, which leads to the product shortage. For example, one of the respondents, R5, mentioned, "we could not get all the SKU (Stock Keeping Unit) available at a time in the same delivery during the crisis period." Sometimes, it is found that the big retailers take more products during the delivery, which causes the product shortage to the small retailer. One of the respondents, R15 stated, "most of the time the retailer with small, ordered quantity could not get their product because of the additional requirement by the big retailer during the delivery period." The respondents identify irregularity in delivery, which is another concern that interrupts the supply. The government restricts the vehicle movement during the early stage of COVID-19 in Bangladesh. It leads to irregularity in delivery to the retailer. For instance, R4 stated, "as per government restriction, vehicle movement during the crisis period is limited. As a result, we could not get the delivery in scheduled date." In the same vine, R2 mentioned, "we could not get delivery in schedule date as per the government restriction during the crisis period."

Generally, retailers get their delivery of the products in front of their retail stores but during the crisis period, they can hardly get the delivery service in their retail stores. R7 mentioned, "we used to get the delivery service in front of our retail in a normal period but now the roads are blocked by the fence for limiting vehicle movement during the crisis period. We have to go to the wholesalers to receive the product." Sometimes, retailers need to visit the distributor to get the products to fulfill their short SKU. In this case, they use their vehicle or rented vehicle and use an alternative route for getting delivery of their own cost. For example, R12 stated, "we could not get the proper delivery service during the crisis period because of limited vehicle movement. Sometimes, we go to the distributor for products." Interruption of the payment to the supplier is found to be another reason that interrupts the supply. Usually, every retailer has a certain amount for purchasing a product for a certain period. Due to the irregularity in delivery time, sometimes retailers spend the allocated money on one product to buy another one. This is mainly because once they get the delivery of a product, they tend to buy more quantity. For example, R16 stated, "every retailer has a budget for a particular product, if the delivery could not arrive on the scheduled date, then it is difficult to maintain on-time payment." Besides, R10 mentioned, "being uncertain of the delivery during the crisis period, we cannot take the required product by giving cash on time." The respondent mentioned that the final supply disruption of beauty and personal care retailers is the limited credit service. Most of the retailers generally get the credit facility from distributors depending on the relationship as well as sales volume. Unfortunately, this credit facility from the distributor is not visible during this crisis period. R14 mentioned, "we get credit facility from distributor during the normal period but now the distributor does the cash business because of high demand for beauty and personal care products during the crisis period." In the same vein, R13 stated, "the distributors claim that they could not get credit facility from the company during the crisis period, so they are not able to give any credit facility to us." Table 2 summarizes the supply interruptions of retailers of beauty and personal care products:

\subsection{Strategies to improve the supply resilience}

The study not only investigates the supply disruption of retailers of beauty and personal care but also explores the strategies to tackle or minimize the disruption. Although the strategies
Enhancing supply resilience in the pandemic 
MSCRA

2,3

150

cannot remove the interruption but can enhance the resilience capabilities to the changing environment. The strategies are linked with each of the supply disruption reasons that interrupt the supply of beauty and personal care retailers. The strategies that are found from the interviews to improve supply resilience of retailers are discussed in details with pointwise:

4.2.1 Focus on product availability rather than brand. The respondents suggest that during such a crisis period, they focus on the product availability, rather than brand, to minimize the product shortage. Their opinion is that no customer will be returned in case of product shortage, they try to push alternative brand to meet the needs in this crisis period. For example, R5 stated, "we have found that the majority of customers are searching for the generic product rather than brand during the crisis period. So, we focus on making the product available in our retail rather than brand preference." In the same vein, R12 said, "we believe if we have available stock of whatever brand, none of the customers will return from our retail." This finding suggests that retailers always want to maximize product availability to enhance the better shopping experience of consumers (Alexander et al., 2002). Retailers prefer to store similar types of products of the different brands so that they can offer those products to the customer rather than losing the customer by telling about the unavailability of products. One of the cornerstones of a successful retailer is to make a good product available in the retail store (Alexander et al., 2002). The findings of this study also suggest that retailers need to put more emphasis on product availability and not to stick to one brand only (Steinhart et al., 2013). May be form different brands but ensuring product readiness for the customer is the main priority.

4.2.2 Develop cooperation. To avoid limited delivery service and interruption of supplier payment, retailers feel that developing strong cooperation with the distributor and company personnel is important. For example, R9 mentioned, "we have a good relationship with the company personnel as well as distributors. When they need to fulfill their monthly target, we help them. In the same way, company personnel also take care of us regarding our product requirement and other trade facilities if they have." Besides, R11 stated, "relation is the key factor to solve any problem. We develop cooperation from the beginning of the business." This strategy suggests that the cooperation between the retailer and company personnel or other stakeholders related to product delivery is highly needed to face the supply challenges. The frameworks of cooperation and social capital theory also suggest to develop cooperation among the members (Sharma and Yetton, 1996). Effective cooperation means all parties are working for mutual benefits and agreeing on helping each other. Sharing information, assisting during the times of product shortage, prioritizing specific retailers while delivering products are the result of cooperation (Chowdhury et al., 2019).

4.2.3 Order bulk quantity. The discussion with the retailers reveals that ordering bulk quantity is effective to minimize the product shortage. The extra quantity of products will minimize the risk whenever there is an irregularity of product delivery. For example, R8 mentioned, "it is very difficult to get all SKU at the same time, so, it is a wise decision to order the bulk quantity on the available SKU." Sometimes, small retailers cannot get their required

Table 2.

Supply interruptions of retailers of beauty and personal care products

\begin{tabular}{|c|c|c|c|c|c|c|c|c|c|c|c|c|c|c|c|c|}
\hline Interruptions & $\begin{array}{l}\mathrm{Ca} \\
\mathrm{A}\end{array}$ & B & $\mathrm{C}$ & $\mathrm{D}$ & $\mathrm{E}$ & $\mathrm{F}$ & G & $\mathrm{H}$ & $\mathrm{I}$ & $\mathrm{J}$ & $\mathrm{K}$ & $\mathrm{L}$ & M & $\mathrm{N}$ & $\mathrm{O}$ & $\mathrm{P}$ \\
\hline Product shortage $(\mathrm{F} 1)$ & $*$ & $*$ & $*$ & $*$ & $*$ & $*$ & $*$ & $*$ & $*$ & $*$ & $*$ & $*$ & $*$ & $*$ & $*$ & * \\
\hline Irregularity product delivery (F2) & $*$ & $*$ & $*$ & & $*$ & $*$ & $*$ & & $*$ & $*$ & & & $*$ & $*$ & & $*$ \\
\hline Limited delivery service (F3) & $*$ & $*$ & $*$ & $*$ & $*$ & & $*$ & & $*$ & $*$ & $*$ & & & $*$ & $*$ & $*$ \\
\hline $\begin{array}{l}\text { Interruption of supplier payment } \\
\text { (F4) }\end{array}$ & $*$ & & $*$ & $*$ & $*$ & & $*$ & $*$ & $*$ & $*$ & $*$ & & $*$ & $*$ & $*$ & $*$ \\
\hline Limited credit facility (F5) & $*$ & $*$ & $*$ & & $*$ & $*$ & $*$ & & $*$ & $*$ & & $*$ & $*$ & & $*$ & $*$ \\
\hline
\end{tabular}


product because of the additional requirement by big retail stores. To avoid this problem, the small retailers can order bulk quantity instead of giving orders two or three times in the same week or month. For example, R6 mentioned, "to avoid the delivery uncertainty, the small retail can give a bulk order at a time in the same week/ month rather than giving $2 / 3$ times order in the same week/ month." In general, retailers have a targeted sales volume of products for each day and according to that they order the products in every two- or three-day intervals. Now while global pandemic hits the supply chain, the frequency of delivery becomes uncertain. Most of the time the retailer cannot get all SKU at a time. As a result, most of the respondents focus on ordering bulk quantity of the SKU that are available. A big quantity or bulk order also helps to get few other benefits including a permission for delayed payment (Yang, 2020).

4.2.4 Develop a mutual cash and credit ratio. Retailers focus on developing a mutual cash and credit ratio to avoid the limited credit facility problem. For instance, R8 mentioned, "we sit with the distributor to give a proposal of 60 percent cash and 40 percent credit ratio to survive during the crisis period." In the same vein, R4 stated, "we believe the cooperation can solve the problem. We will discuss and decide the cash and credit ratio with our suppliers." By fixing the ratio retailers believe that they can get many advantages and solve the problems related to liquidity crisis. All the supply chain partners including manufacturers and distributors are severely affected by the coronavirus pandemic. As a result, the distributor cannot give $100 \%$ credit facility like previous practice. In this regard, such a cash and credit ration can be effective to minimize the problem (Acharya et al., 2013). This finding suggests that as the problem of credit facility increases, the trade-off between cash and credit lines becomes more important (Acharya et al., 2013).

4.2.5 Intensive interaction. The study also reveals that retailers focus on intensive interaction to avoid the irregular delivery. For example, R3 stated, "we have a regular touch with company personnel over the phone regarding the delivery details which minimize the communication gap between us." In the same vein, R1 mentioned, "we have the contact number of the person who is responsible for delivery. Sometimes, they call us one day before the delivery which helps us to take preparation." Interaction can take place through a mobile phone or on any social media platform (Hewett and Nind, 2013). Interaction between retailers and company personnel is inevitable for doing business. When the interaction becomes intensive, frequent and social, it helps to build a personal relationship (Chowdhury et al., 2019).

The aforementioned strategies are implemented by the respondents of this study. They believe that these strategies are effective for enhancing the supply resilience by minimizing the effects of the COVID-19 pandemic on the supply of beauty and personal care products.

\section{Managerial implications}

The COVID-19 pandemic is responsible for many difficulties in retail supply chains (Bryce et al., 2020) especially when the normal business mechanism is behaving unusual (Barua, 2020 ) and restrictions are imposed to vehicles mobility and also people's movement (Budd and Ison, 2020). Being focused on beauty and personal care products, adaptable strategies are taken to ensure product availability from the retailer's end. Understandings of disruption caused in the supply of retailers are crucial as without such knowledge effective strategies cannot be formulated to improve supply resilience during the COVID-19. Indeed, understandings of effects in a comprehensive manner is helpful for managerial decision making (Dwivedi et al., 2019; Moktadir et al., 2020). This study explores and explains how the supply of beauty and personal care retailers is disrupted and put together five strategies for managers to ensure uninterrupted product flow for the business. The main lessons from the findings of this study are discussed as follows. 
MSCRA

2,3

152

(1) Managers of retail stores need to focus on different brand products rather than depending on one single brand to guarantee its supply of products. Customers are adjusting their habit of using product regarding any specific brands. Retailers must store similar kinds of products of different brands so that when one manufacturing company fails to deliver products then, retailers can sell other brands' products and meet customer demand, which will minimize the supply risk of retailers to a great extent.

(2) Managers of retail stores need to follow a cooperative approach with the company personal, which can be one of the finest ways for retailers to face the current stagnant of product supply and find a viable solution for themselves. Both helping each other to fulfill their target, making future promises to look after each other, giving business advantages and coming forward when one faces difficulties to run the business operation are vital to make a successful collaboration between them. When collaboration is there, it seems easy to cope during a major supply chain interruption.

(3) Managers can order bulk quantity or order more volume than before as a safeguard to deal with the shortage of products during this crisis period. Retailers can follow this approach to improve the service level. Whenever one or two delivery misses by the company personnel, it will work as a safety stock and will not affect the product supply of the firms (Darom et al., 2018; Zsidisin, 2003).

(4) Managers of the retail stores need to adapt a new ratio of credit or cash facility to overcome the problem of credit facility. Retailers generally receive the credit facility from the suppliers. However, the current pandemic situation is not ideal for this facility as all partners are in trouble. A new credit ration facility will assist to survive this turmoil situation and reduce the risk associated with the retailer's supply.

(5) Managers should develop an effective relationship and maintain frequent interaction with the individual who is responsible for delivering the product. It helps managers to know about the product information beforehand. This assists retailers to prepare for any kind of situation proactively. Managers can communicate with company personnel through social media or mobile phones. Moreover, interactions can take place face to face by following the COVID-19 social distancing rules. Managers can do some chats with the delivery person in retailers' shops or any other local shop by which useful information can be exchanged.

This global pandemic is the reason why many challenges and businesses are facing new kinds of supply risks to ensure their products in-store. The reasons found in this paper are the general problems faced by most retailers who are dealing with beauty and personal care products. The strategies formulated against the supply problems are important for managers to deal with the current situation and enhance the supply resilience in their firms.

\section{Conclusion and future research directions}

A resilient supply is the precondition of maintaining smooth and uninterrupted product flow from manufacturer to retailers. Global pandemic like the COVID-19 disrupts the current supply management of companies and retailers and their regular operations (Ivanov, 2020a, b). This study reveals five main effects of the COVID-19 pandemic in supply of beauty and personal care products. These include product shortage, delivery irregularity, limited services than before, supplier payment difficulties and the limited credit facility. The study also suggests some strategies to ensure supply resilience, which are focusing on various brands, developing cooperation, ordering bulk quantity, developing a credit and cash ratio and maintaining intensive interaction. 
By exploring how the supply of retailers is interrupted and how retailers can manage the interruption to ensure supply resiliency, this study contributes to the knowledge of the retail supply chain during a pandemic. Such knowledge is a novel contribution of this study. Moreover, studies on the supply management of retailers are currently limited. On the other hand, many studies can be found in the supply management of manufacturers (Chowdhury et al., 2019; Yeung, 2008). This study also contributes to the supply management and resilience of retailers. Moreover, enhancing supply chain resilience in the COVID-19 situation by taking proper strategies can contribute to the survival of the retailers. As the context is a developing country, the study has also contributed to the literature on developing counties. Currently, literature on supply chain and operations management in the context of developing counties is limited (Karuppiah et al., 2020; Tumpa et al., 2019).

While the paper contributes substantially, it also has some limitations. The research context is limited to a small area. Since this is a qualitative study, some issues such as validity and generalizability are the limitations of the study (Yin, 2009). The paper is based on the interviews of the retailers of beauty and personal care products. As supply interruption can vary from one product category to another product category, future studies could potentially explore the supply resilience of retailers of other products. Moreover, a future study using a mass scale survey could be undertaken to enhance the generalizability of the findings of our study. A future study could also analyze and rank the disruptions factors and resilience strategies, found in this study, using a multicriteria decision making (MCDM) tool. MCDM is a useful tool for decision-making (Chowdhury and Paul, 2020; Moktadir et al., 2020); hence, such as study can substantially contribute to the managerial decision-making. The geographical context of research can also be shifted in future studies, that is, taking a developed country context and comparing its outputs with our findings to portray the differences between different contexts. From the comparison, maybe new strategies can be found to handle the situation more effectively.

\section{References}

Abir, A.A. (2019), "Retail industry in Bangladesh: a different shape up story", Light Castle Analytics Wing, available at: https://databd.co/stories/organized-retail-industry-outlook-bangladesh 2077\#: :text=Retail $\% 20$ environment $\% 20$ in $\% 20$ Bangladesh $\% 20$ can,new $\% 20$ generation $\%$ 20convenience $\% 20$ seeking $\% 20$ consumers (accessed 20 July 2020).

Acharya, V.V., Almeida, H. and Campello, M. (2013), "Aggregate risk and the choice between cash and lines of credit", The Journal of Finance, Vol. 68 No. 5, pp. 2059-2116.

Alexander, K., Birkhofer, G., Gramling, K., Kleinberger, H., Leng, S., Moogimane, D. and Woods, M. (2002), Focus on Retail: Applying Auto-ID to Improve Product Availability at the Retail Shelf, White Paper, Auto-ID Center, MIT, Cambridge.

Ali, S.M. and Nakade, K. (2017), "Optimal ordering policies in a multi-sourcing supply chain with supply and demand disruptions-a CVaR approach”, International Journal of Logistics Systems and Management, Vol. 28 No. 2, pp. 180-199.

Ambulkar, S., Blackhurst, J. and Grawe, S. (2014), "Firms resilience to supply chain disruptions: scale development and empirical examination", Journal of Operations Management, Vol. 33 No. 34, pp. 111-122.

Bahroun, M. and Harbi, S. (2016), "Risk management in the modern retail supply chain: lessons from a case study and literature review", Proceedings of 2015 International Conference on Industrial Engineering and Systems Management, IEEE IESM 2015, Institute of Electrical and Electronics Engineers, pp. 1161-1170.

Barua, S. (2020), "Understanding coronanomics: the economic implications of the coronavirus (COVID-19) pandemic”, SSRN Electronic Journal. doi: 10/ggq92n (accessed 24 July 2020).
Enhancing supply resilience in the pandemic 
MSCRA

2,3

Bhuiyan, M.S.A. (2020), "Covid-19 and its impact on Bangladesh economy”, The Business Standard, available at: https://tbsnews.net/thoughts/covid-19-and-its-impact-bangladesh-economy69541 (accessed 20 July 2020).

Blackhurst, J., Dunn, K. and Craighead, C. (2011), "An empirically derived framework of global supply resiliency”, Journal of Business Logistics, Vol. 32 No. 4, pp. 374-391.

Blos, M.F. and Wee, H.M. (2020), "A supply chain vulnerability map for the Automotive and Electronic industries in Brazil", International Journal of Service Management and Sustainability, Vol. 3 No. 2, pp. 83-95.

Bogataj, D. and Bogataj, M. (2007), "Measuring the supply chain risk and vulnerability in frequency space”, International Journal of Production Economics, Vol. 108, pp. 291-301.

Bryce, C., Ring, P., Ashby, S. and Wardman, J.K. (2020), "Resilience in the face of uncertainty: early lessons from the COVID-19 pandemic", Journal of Risk Research. doi: 10.1080/13669877.2020. 1756379 .

Budd, L. and Ison, S. (2020), "Responsible Transport: a post-COVID agenda for transport policy and practice", Transportation Research Interdisciplinary Perspectives, Vol. 6, p. 100151.

Chalabi, M. (2020), "Coronavirus is revealing how broken America's economy really is", The Gurdian, available at: https://www.theguardian.com/news/datablog/2020/apr/06/coronavirus-americanreaction-economy-covid-19?fbclid=IwAR0p7T8nd5TUPIIQKhlcXWsTTX7s2Q6TDT3UoW0Z OgjsGjIt11Hr3W75a50 (accessed 20 July 2020).

Chowdhury, P. and Paul, S.K. (2020), "Applications of MCDM methods in research on corporate sustainability: a systematic literature review”, Management of Environmental Quality, Vol. 31 No. 2, pp. 385-405.

Chowdhury, P., Lau, K.H. and Pittayachawan, S. (2016), "Supply risk mitigation of small and medium enterprises: a social capital approach", The Proceedings of 21st International Symposium on Logistics, Centre for Concurrent Enterprise, Nottingham University, Nottingham, pp. 37-44.

Chowdhury, P., Lau, K.H. and Pittayachawan, S. (2019), "Operational supply chain risk mitigation of SME and its impacts on operational performance: a social capital perspective", International Journal of Operation and Production Management, Vol. 39 No. 4, pp. 478-502.

Chowdhury, M.T., Sarkar, A., Paul, S. and Moktadir, M.A. (2020), "A case study on strategies to deal with the impacts of COVID-19 pandemic in the food and beverage industry", Operations Management Research. doi: 10.1007/s12063-020-00166-9.

Christopher, M. and Peck, H. (2004), "Building the resilient supply chain”, International Journal of Logistics Management, Vol. 15 No. 2, pp. 1-14.

Darom, N.A., Hishamuddin, H., Ramli, R. and Mat Nopiah, Z. (2018), "An inventory model of supply chain disruption recovery with safety stock and carbon emission consideration", Journal of Cleaner Production, Vol. 197, pp. 1011-1021.

De Sousa Jabbour, A.B.L., Jabbour, C.J.C., Hingley, M., Vilalta-Perdomo, E.L., Ramsden, G. and Twigg, D. (2020), "Sustainability of supply chains in the wake of the coronavirus (COVID-19/ SARS-CoV-2) pandemic: lessons and trends", Modern Supply Chain Research and Applications. doi: 10.1108/MSCRA-05-2020-0011.

Dwivedi, A., Agrawal, D. and Madaan, J. (2019), "Sustainable manufacturing evaluation model focusing leather industries in India- A TISM approach", Journal of Science and Technology Policy Management, Vol. 10 No. 2, p. 319359.

Eisenhardt, K.M. (1989), "Building theories from case study research", Academy of Management Review, Vol. 14 No. 4, pp. 532-550.

Fartaj, S.-R., Kabir, G., Eghujovbo, V., Ali, S.M. and Paul, S.K. (2019), "Modeling transportation disruptions in the supply chain of automotive parts manufacturing company", International Journal of Production Economics, Vol. 222 No. 107511, pp. 1-15.

Fiksel, J. (2006), "Sustainability and resilience: toward a systems approach", Sustainability: Science, Practice and Policy, Vol. 2 No. 2, pp. 1-8. 
Fleisch, E. and Tellkamp, C. (2005), "Inventory inaccuracy and supply chain performance: a simulation study of a retail supply chain", International Journal of Production Economics, Vol. 95 No. 3, pp. 373-385.

Fortune (2020), "Fortune 1000", available at: https://fortune.com/2020/02/21/fortune-1000- coronaviruschina-supply-chain-impact/ (accessed 20 July 2020).

Enhancing supply resilience in the pandemic

Ge, D., Pan, Y. and Zhang, C. (2019), "Retail supply chain management: a review of theories and practices", Journal of Data, Information, and Management, Vol. 1, pp. 45-64.

Golan, M.S., Jernegan, L.H. and Linkov, I. (2020), "Trends and applications of resilience analytics in supply chain modeling: systematic literature review in the context of the COVID19 pandemic", Environment Systems and Decisions, Vol. 40, pp. 222-243.

Gunasekaran, A., Subramanian, N. and Rahman, S. (2015), "Supply chain resilience: role of complexities and strategies", International Journal of Production Research, Vol. 53 No. 22, pp. 6809-6919.

Gupta, V., Ivanov, D. and Choi, T.-M. (2020), “Competitive pricing of substitute products under supply disruption”, Omega. doi: 10.1016/j.omega.2020.102279.

Hewett, D. and Nind, M. (2013), Interaction in Action: Reflections on the Use of Intensive Interaction, David Fulton Publishers.

Hobbs, J.E. (2020), "Food supply chains during the COVID-19 pandemic", Canadian Journal of Agricultural Economics, Vol. 68 No. 2, pp. 171-176.

Hoek, R.V. (2020), "Research opportunities for a more resilient post-COVID-19 supply chain - closing the gap between research findings and industry practice", International Journal of Operations and Production Management, Vol. 40 No. 4, pp. 341-355.

Huda, M.M. and Sultan, P. (2013), "Buying motives of herbal skin care products: the case of generation Y in Bangladesh”, International Review of Business Research Papers, Vol. 9 No. 5, pp. $68-80$.

Hudecheck, M., SirenGrichnik, C.D. and Wincent, J. (2020), "How companies can respond to the coronavirus", MIT Sloan Management Review, available at: https://sloanreview.mit.edu/article/ how-companies-can-respond-to-the-coronavirus/ (accessed 24 July 2020).

ILO (2020), "COVID-19 and the world of work: impact and policy responses", ILO Monitor 1st Edition, available at: https:/www.ilo.org/wcmsp5/groups/public/- -dgreports/-dcomm/documents/ briefingnote/wcms_738753.pdf (accessed 24 July 2020).

Islam, M.T., Azeem, A., Jabir, M., Paul, A. and Paul, S.K. (2020), "An inventory model for a three-stage supply chain with random capacities considering disruptions and supplier reliability", Annals of Operations Research. doi: 10.1007/s10479-020-03639-z.

Ivanov, D. (2020a), "Predicting the impacts of epidemic outbreaks on global supply chains: a simulation-based analysis on the coronavirus outbreak (COVID-19/SARS-CoV-2) case", Transportation Research Part E: Logistics and Transportation Review, Vol. 136, p. 101922.

Ivanov, D. (2020b), "Viable supply chain model: integrating agility, resilience and sustainability perspectives: lessons from and thinking beyond the COVID-19 pandemic", Annals of Operations Research. doi: 10.1007/s10479-020-03640-6.

Kahiluoto, H. and Makinen, H. (2019), "Supplying resilience through assessing diversity of responses to disruption", International Journal of Operations and Production Management, Vol. 40 No. 3, pp. 271-292.

Karuppiah, K., Sankaranarayanan, B., Ali, S.M., Chowdhury, P. and Paul, S.K. (2020), "An integrated approach to modelling the barriers in implementing green manufacturing practices in SMEs", Journal of Cleaner Production, Vol. 265, p. 121737.

Koonin, L.M. (2020), "Novel coronavirus disease (COVID-19) outbreak: now is the time to refresh pandemic plans", Journal of Business Continuity and Emergency Planning, Vol. 13 No. 4, pp. 1-15. 
MSCRA

2,3

Kumar, M.S., Raut, D.R.D., Narwane, D.V.S. and Narkhede, D.B.E. (2020), "Applications of industry 4.0 to overcome the COVID-19 operational challenges", Diabetes and Metabolic Syndrome: Clinical Research Reviews, Vol. 14, pp. 1283-1289.

Kwak, D.W., Seo, Y.J. and Mason, R. (2018), "Investigating the relationship between supply chain innovation, risk management capabilities and competitive advantage in global supply chains", International Journal of Operations and Production Management, Vol. 38 No. 1, pp. 2-21.

Laing, T. (2020), "The economic impact of the Coronavirus 2019 (Covid-2019): implications for the mining industry", The Extractive Industries and Society, Vol. 7 No. 2, pp. 580-582.

Lin, Q., Zhao, S., Gao, D., Lou, Y., Yang, S., Musa, S.S., Wang, M.H., Cai, Y., Wang, W., Yang, L. and He, D. (2020), "A conceptual model for the coronavirus disease 2019 (COVID-19) outbreak in Wuhan, China with individual reaction and governmental action", International Journal of Infectious Diseases, Vol. 93, pp. 211-216.

Masory, A. (2019), "Naturally beautiful: millennials and preferences in beauty and personal care products", available at: https://www.alixpartners.com/insights-impact/insights/millennialspreferences-beauty-personal-care-products/ (accessed 24 July 2020).

Mitroff, I. and Alpasan, M. (2003), "Preparing for evil", Harvard Business Review, April, pp. 109-115, available at: https://hbr.org/2003/04/preparing-for-evil (accessed 20 July 2020).

Moktadir, M.A., Dwivedi, A., Rahman, A., Chiappetta Jabbour, C.J., Paul, S.K., Sultana, R. and Madaan, J. (2020), "An investigation of key performance indicators for operational excellence towards sustainability in the leather products industry", Business Strategy and the Environment. doi: 10.1002/bse.2575.

Paul, S.K. and Chowdhury, P. (2020a), "A production recovery plan in manufacturing supply chains for a high-demand item during COVID-19", International Journal of Physical Distribution and Logistics Management, pp. 1-22, doi: 10.1108/IJPDLM-04-2020-0127.

Paul, S.K. and Chowdhury, P. (2020b), "Strategies for managing the impacts of disruptions during COVID-19: an example of toilet paper", Global Journal of Flexible Systems Management, Vol. 21 No. 3, pp. 283-293.

Paul, S.K. and Rahman, S. (2018a), "A quantitative and simulation model for managing sudden supply delay with fuzzy demand and safety stock", International Journal of Production Research, Vol. 56 No. 13, pp. 4377-4395.

Paul, S.K. and Rahman, S. (2018b), "A recovery model for sudden supply delay with demand uncertainty and safety stock", in Sarker, R., Abbass, H., Dunstall, S., Kilby, P., Davis, R. and Young, L. (Eds), Data and Decision Sciences in Action, Lecture Notes in Management and Industrial Engineering, pp. 243-257, Springer, Cham, doi: 10.1007/978-3-319-55914-8_18.

Paul, S.K., Sarker, R. and Essam, D. (2014a), "Real time disruption management for a two-stage batch production-inventory system with reliability considerations", European Journal of Operational Research, Vol. 237 No. 1, pp. 113-128.

Paul, S.K., Sarker, R. and Essam, D. (2014b), "Managing real-time demand fluctuation under a supplier-retailer coordinated system", International Journal of Production Economics, Vol. 158, pp. 231-243.

Paul, S.K., Sarker, R. and Essam, D. (2015a), "Managing disruption in an imperfect productioninventory system", Computers and Industrial Engineering, Vol. 84, pp. 101-112.

Paul, S.K., Sarker, R. and Essam, D. (2015b), "A disruption recovery plan in a three-stage productioninventory system", Computers and Operations Research, Vol. 57, pp. 60-72.

Paul, S.K., Sarkar, R. and Essam, D. (2016), "Managing risk and disruption in production -inventory and supply chain systems: a review", Journal of Industrial and Management Optimization, Vol. 12 No. 3, pp. 1009-1029.

Paul, S.K., Sarker, R. and Essam, D. (2017), “A quantitative model for disruption mitigation in a supply chain”, European Journal of Operational Research, Vol. 257 No. 3, pp. 881-895. 
Paul, S.K., Sarker, R. and Essam, D. (2018), "A reactive mitigation approach for managing supply disruption in a three-tier supply chain”, Journal of Intelligent Manufacturing, Vol. 29 No. 7, pp. 1581-1597.

Paul, S.K., Sarker, R., Essam, D. and Lee, P.T.W. (2019b), "A mathematical modelling approach for managing sudden disturbances in a three-tier manufacturing supply chain", Annals of Operations Research, Vol. 280 Nos 1-2, pp. 299-335.

Paul, S.K. (2015), "Supplier selection for managing supply risks in a supply chain: a fuzzy approach", International Journal of Advanced Manufacturing Technology, Vol. 79 Nos 1-4, pp. 657-664.

Pettit, T.J., Fiksel, J. and Croxton, K.L. (2010), "Ensuring supply chain resilience: development of a conceptual framework", Journal of Business Logistics, Vol. 31 No. 1, pp. 1-21.

Ponomarov, S.Y. and Holcomb, M.C. (2009), "Understanding the concept of supply chain resilience", International Journal of Logistics Management, Vol. 20 No. 1, pp. 124-143.

Saha, A., PaulAzeem, A.A. and Paul, S.K. (2020), "Mitigating partial-disruption risk: a joint facility location and inventory model considering customers' preferences and the role of substitute products and backorders", Computers and Operations Research, Vol. 117 No. 104884, pp. 1-26.

Salehi Sadghiani, N., Torabi, S.A. and Sahebjamnia, N. (2015), "Retail supply chain network design under operational and disruption risks", Transportation Research Part E: Logistics and Transportation Review, Vol. 75, pp. 95-114.

Sarkar, S. and Kumar, S. (2015), "A behavioral experiment on inventory management with supply chain disruption”, International Journal of Production Economics, Vol. 169, pp. 169-178.

Sharma, R. and Yetton, P. (1996), "Interorganizational cooperation to develop information systems", ICIS 1996 Proceedings, p. 9.

Sharma, A., Adhikary, A. and Borah, S.B. (2020), "Covid-19's impact on supply chain decisions: strategic insights from NASDAQ 100 firms using Twitter data", Journal of Business Research, Vol. 117, pp. 443-449.

Signori, P., Flint, D.J. and Golicic, S. (2015), "Toward sustainable supply chain orientation (SSCO): mapping managerial perspectives", International Journal of Physical Distribution and Logistics Management, Vol. 45 No. 6, pp. 536-564.

Sparks, L. (2010), "Supply chain management and retailing", Supply Chain Forum, Vol. 11 No. 4, pp. 4-12.

Steinhart, Y., Mazursky, D. and Kamins, M.A. (2013), "The process by which product availability triggers purchase”, Marketing Letters, Vol. 24 No. 3, doi: 10.1007/s11002-013-9227-4.

Tang, C.S. (2006), "Perspective in supply chain risk management", International Journal of Production Economics, Vol. 103 No. 2, pp. 451-488.

Tumpa, T.J., Ali, S.M., Rahman, M.H., Paul, S.K., Chowdhury, P. and Rehman Khan, S.A. (2019), "Barriers to green supply chain management: an emerging economy context", Journal of Cleaner Production, Vol. 236, pp. 1-12.

UNB (2020), “ADB forecasts developing Asian economies in recession”, available at: http://unb.com. bd/category/World/adb-forecasts-developing-asian-economies-in-recession/57437 (accessed 19 September 2020).

Wagner, S.M. and Bode, C. (2006), "An empirical investigation into supply chain vulnerability", Journal of Purchasing and Supply Management, Vol. 12, pp. 301-312.

Wagner, S.M. and Neshat, N. (2010), "Assessing the vulnerability of supply chains using graph theory", International Journal of Production Economics, Vol. 126, pp. 121-129.

Wang, X. and Liu, L. (2007), "Coordination in a retailer-led supply chain through option contract", International Journal of Production Economics, Vol. 110 Nos 1-2, pp. 115-127.

Wielend, A. and Wallenburg, C. (2013), "The influence of rational competencies on supply resilience: a rational view", International Journal of Physical Distribution and Logistics Management, Vol. 43 No. 4, pp. 300-320.

Enhancing supply

resilience in the pandemic

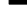


MSCRA

2,3

158

World Bank (2020), "Global economic prospects", available at: https://www.worldbank.org/en/ publication/global-economic-prospects (accessed 24 July 2020).

Yang, H.L. (2020), "Retailer's ordering policy for demand depending on the expiration date with limited storage capacity under supplier credits linked to order quantity and discounted cash flow", International Journal of Systems Science: Operations and Logistics. doi: 10.1080/23302674. 2019.170172.

Yeung, A.C.L. (2008), "Strategic supply management, quality initiatives, and organizationalperformance", Journal of Operations Management, Vol. 26 No. 4, pp. 490-502.

Yin, R.K. (2009), Case Study Research: Design and Methods, Sage, Thousand Oaks, CA.

Yu, K.D.S. and Aviso, K.B. (2020), "Modelling the economic impact and ripple effects of disease outbreaks", Process Integration and Optimization for Sustainability, Vol. 4, pp. 183-186.

Yuen, K.F., Wang, X., Ma, F. and Li, K.X. (2020), "The psychological causes of panic buying following a health crisis", International Journal of Environmental Research and Public Health, Vol. 17, pp. 1-14.

Zsidisin, G.A. (2003), "A grounded definition of supply risk", Journal of Purchasing and Supply Management, Vol. 9 No. 5, pp. 217-224.

\section{Further reading}

Farhin, N. (2017), "Bangladesh sixth largest buyer of cosmetics in the muslim world", Dhaka Tribune, available at: https://www.dhakatribune.com/business/2017/06/05/bangladesh-buyer-cosmeticsmuslim (accessed 20 July 2020).

Fiksel, J. (2003), "Designing resilient sustainable systems", Environmental Science and Technology, Vol. 37 No. 23, pp. 5330-5339.

Hishamuddin, H. and Bazin, N. (2019), "A system dynamics approach to investigate the effects of disruption on the supply chain with A mitigation strategy", IOP Conference Series: Materials Science and Engineering, Vol. 697 No. 1, pp. 1-12.

Paul, S.K., AsianGoh, S.M. and Torobi, S.A. (2019a), "Managing sudden transportation disruptions under delivery delay and quantity loss", Annals of Operations Research, Vol. 273 Nos 1-2, pp. 783-814.

\section{Appendix \\ Interview Protocol}

\section{Opening}

Thank you so much for your valuable time. First, I would like to briefly explain the project to you. The broad objectives of this project are two: (1) to understand the effect of the COVID-19 on the supply of beauty and personal care retailers; and (2) to explore the strategies that can be undertaken to improve the supply resilience.

You are selected because you manage a retail store of beauty and personal care products. The anonymity and confidentiality of your response will be strictly maintained. You also can withdraw from this project anytime without explaining the reasons.

\section{Interview questions}

(1) How long have you been in the retail business?

(2) How many employees do you have in your firm? 
(3) How does COVID-19 affect your supply of beauty and personal care products?

Enhancing

(4) What strategies have you implemented to improve your supply resilience?

(5) What other strategies could be undertaken in this situation?

supply

resilience in the

pandemic

Floating Prompts

Can you please explain in detail about this?

That is very thoughtful; can you please continue to explain for better understanding?

Can you please give any practical example to understand the incident to a broader extent?

\section{Closing}

Thank you very much for your interactive participation. We will give you a copy if you want for future reference. It would be appreciable if you call me for any queries.

\section{Corresponding author}

Md. Tarek Chowdhury can be contacted at: md.tarekchowdhury@yahoo.com

For instructions on how to order reprints of this article, please visit our website:

www.emeraldgrouppublishing.com/licensing/reprints.htm

Or contact us for further details: permissions@emeraldinsight.com 